Portland State University

PDXScholar

$1-2015$

\title{
Socioeconomic Disparities in the Provision of Outdoor Time in Portland, Oregon Public Elementary Schools
}

Sabine L. Lefkowitz

Portland State University

Follow this and additional works at: https://pdxscholar.library.pdx.edu/honorstheses

Let us know how access to this document benefits you.

\section{Recommended Citation}

Lefkowitz, Sabine L., "Socioeconomic Disparities in the Provision of Outdoor Time in Portland, Oregon Public Elementary Schools" (2015). University Honors Theses. Paper 117.

https://doi.org/10.15760/honors.118

This Thesis is brought to you for free and open access. It has been accepted for inclusion in University Honors Theses by an authorized administrator of PDXScholar. Please contact us if we can make this document more accessible: pdxscholar@pdx.edu. 
OUTDOOR TIME IN PORTLAND ELEMENTARY SCHOOLS

Socioeconomic Disparities in the Provision of Outdoor Time in Portland, Oregon Public Elementary Schools

by

Sabine L. Lefkowitz

An undergraduate honors thesis submitted in partial fulfillment of the requirements for the

degree of

Bachelor of Science

in

University Honors

and

Health Sciences

Thesis Adviser

Kenneth Still, PhD

Portland State University

2015 
OUTDOOR TIME IN PORTLAND ELEMENTARY SCHOOLS

Abstract

This thesis examines the relationship between socioeconomic status (SES) and the amount of outdoor time in public elementary schools in Portland, Oregon. "Outdoor time" is defined as the percentage of the school day spent at recess. SES is determined based on the percentage of children at each school who receive free or reduced price lunch. Schools with a higher percentage of students who receive free or reduced lunch are considered lower SES than schools with a lower percentage of students who receive free or reduced lunch. A review of the current literature provides evidence that time spent outdoors has a positive effect on children's social skills, ability to concentrate, self-esteem, health and development, whereas low SES is linked to poor literacy, poor health, and behavior problems. Data regarding the frequency and duration of recess, PE, field trips, and school gardens for each of the elementary schools was collected and analyzed. The results of this study indicate that higher SES elementary schools spend more time outdoors than low SES schools. Because SES correlates to academic achievement, children who attend high-poverty schools are already at a disadvantage and a lack of outdoor time amplifies this problem. This study proposes that the Portland Public School system address the inequity regarding school outdoor time and its relationship with SES in order to regain equity between schools and achieve its goal for every student to, "[...] meet or exceed academic standards and [...] be fully prepared to make productive life decisions," (Portland Public Schools, 2014).

Socioeconomic Disparities in the Provision of Outdoor Time in Portland, Oregon Public Elementary Schools 
OUTDOOR TIME IN PORTLAND ELEMENTARY SCHOOLS

The original kindergarten - the children's garden - conceived by German educator Friedrick

Froebel in the $19^{\text {th }}$ century was a place where children learned through play, often in nature.

-Sobel, 2014

\section{Introduction}

My thesis question is: What is the relationship between socioeconomic status and the amount time spent outside at Portland public elementary schools?

The majority of school children receive their education indoors and many children often spend after school time indoors as well, due to increasing access and use of virtual devices such as TVs, cell phones, and computers. Although these computer games and TV shows can sometimes be educational and help children develop, they are "[...] limited by the mind of the human who created the game. In a tree, a woods, a field, a mountain, a ravine, a vacant lot, the number of loose but related parts is unlimited," (Louv, 2011). Some studies have also found that “[...] the reduction in outdoor play and in getting around on foot seriously affects children's physical and psychological development and well-being (Prezza et al., 2005). Obesity, attention disorder, and depression are only some consequences of the disconnection between children and nature, summarized by Richard Louv (2006) as “nature-deficient disorder,"” (LindemannMatthies, 2011). Nature-deficient disorder is a growing concern for the health of children and adults and is of particular interest to counselors and educators. In his books Last Child in the

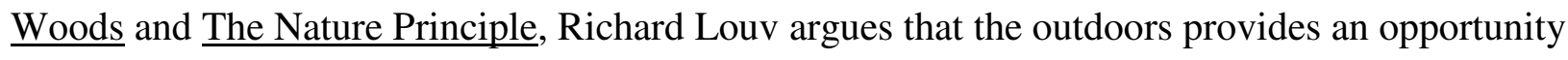
for children to explore and develop in an environment that engages all their senses and leaves questions unanswered, allowing for creativity, spontaneity, and imagination. Where better to gain these skills than at school? 
OUTDOOR TIME IN PORTLAND ELEMENTARY SCHOOLS

Most parents and schools want to provide children with an education that helps prepare them for life. This study aims to help schools achieve this goal by examining the relationship and equity between the amount of time spent outdoors and socioeconomic status of Portland public elementary schools. The goal of Portland Public Schools is that: "By the end of elementary, middle and high school, every student by name will meet or exceed academic standards and will be fully prepared to make productive life decisions," (Portland Public Schools - About Portland Public Schools, 2014). Research in the fields of education, public health, and psychology, suggests a positive correlation between spending time outdoors and the health and development of children. For example, several European forest school studies have found that, when children learn at the outdoor forest school, they have improved confidence, social skills, self-esteem and physical health (Lindemann-Matthies, 2011, Swarbrick, 2004). These skills support Portland public schools' mission to prepare children "to make productive life decisions."

In his book Last Child in the Woods, Louv states that, "in The Human Relationship with Nature, Peter Kahn points to the findings of over one hundred studies that confirm that one of the main benefits of spending time in nature is stress reduction," (2008). For example, a 2003 study performed by Nancy Wells and Gary Evans found that "the effect of stressful life events on children's psychological distress varies as a function of the amount of nearby nature to which the children are exposed. Specifically, the impact of stressful life events on psychological distress is weaker under conditions of high nature than under low nature conditions," (2003). School children who are better able to manage stress will have improved health and ability to learn. The variability in the amount of time spent outdoors at different elementary schools in Portland will reflect a possible inequity among the opportunity for students at different schools to relieve stress and improve their ability to learn. 
OUTDOOR TIME IN PORTLAND ELEMENTARY SCHOOLS

Although outdoor time enhances positive child development, low socioeconomic status (SES) does the opposite. Low SES is linked to poor literacy, poor health, and behavior problems (Buckingham, Wheldall, \& Beaman-Wheldall, 2013). Based on the evidence that nature has a positive effect on health and behavior, children of lower SES may benefit from more time outdoors. A 2008 examination of elementary school recess trends since the enactment of No Child Left Behind found that, "While most children, regardless of location, continue to get recess on a regular basis, children who attend high-minority, high-poverty, or urban [elementary] schools are far more likely than other children to get no recess at all," (Barth, 2008). Because socioeconomic status correlates to academic achievement, children who attend high-poverty schools are already at a disadvantage and a lack of outdoor time amplifies this problem (Sirin, 2005).

This thesis reviews literature regarding outdoor education and the opportunity that spending time outside provides for children to develop the skills to grow, learn and contribute positively to society. This study also examines ways in which Portland public schools currently incorporate outdoor time into the school day. The study further examines inequalities in the amount of outdoor time between Portland elementary schools and its relationship to socioeconomic status. For the purposes of this study "outdoor time" is defined as the percentage of the school day spent at recess. Although recess is not always spent outdoors, and students may perform other activities outside during the school day, recess was chosen to represent outdoor time due to its consistency between schools and its ability to be measured in minutes. Socioeconomic status was measured as the percentage of students at each school who receive free or reduced price lunch. Schools with a higher percentage of students who receive free or reduced price lunch are considered lower SES than schools with a lower percentage of students who receive free or reduced price lunch. Data regarding recess, PE, field trips, socioeconomic 
OUTDOOR TIME IN PORTLAND ELEMENTARY SCHOOLS

status and school gardens was collected and analyzed for 58 of the 61 Portland public elementary schools.

\section{Hypothesis}

My hypothesis is that outdoor time differs between Portland public elementary schools and that students at schools of lower socioeconomic status spend less time outside during the school day than students at higher socioeconomic status schools.

\section{Literature Review}

Unlike television, nature does not steal time; it amplifies it.

-Louv, 2008

In a world that is becoming increasingly virtual, there is growing interest in the fields of education, health, and psychology on the effects of nature on the human mind. The historical discourse on nature and the outdoors provides strong evidence for the positive effects of outdoor education on children's self-esteem, social skills, ability to focus, imagination, ability to handle stress and overall well-being (Jarrett, 2013; Lindemann-Matthies, 2011; Louv, 2008; Sallis, 1999; Swarbrick 2004; Wells, 2003). The growing disconnect between children and nature has gained attention from Richard Louv's books $\underline{\text { The Nature Principle and national bestseller Last }}$ Child in the Woods, which provide an extensive analysis of the decrease in the amount of time children spend outdoors and its negative effects on their social, physical, emotional, and spiritual health and well-being. In these books Louv analyzes numerous studies, some of which this literature review will discuss, and he argues that "a reconnection to the natural world is fundamental to human health, well-being, spirit, and survival," (Louv, 2011). He coins the term "nature-deficit disorder, not as a medical diagnosis, but as a way to describe the growing gap between children and nature," (Louv, 2011). 
OUTDOOR TIME IN PORTLAND ELEMENTARY SCHOOLS

"Outdoor learning increases attention span, enhances memory, reduces stress, improves mood and opens the mind to greater activity," (Randall, 2012). For example, "Studies have found that post-surgical patients recover more smoothly when they can view trees through their hospital windows; that public housing residents enjoy stronger social bonds, less violence, and (among girls) greater concentration, impulse control, and delayed gratification when there are trees near their apartments; and that in neighborhoods with trees, newborns are less likely to be small for gestational age, children are less prone to become overweight, and elders live longer," (Frumkin, 2013). Another study entitled Self-esteem and successful interaction as part of the forest school project by Nick Swarbrick, Glynnis Eastwood and Kris Tutton, found that forest education, in which the classroom is located in a natural setting, encourages children in problemsolving. The "reality" of the outdoor problems children solve can raise their self-esteem and "this in turn helps them to better manage their own behaviour, and to make more proactive life choices," (Swarbrick, 2004). Outdoors, younger children learn to explore, which can provide valuable skills for navigating the world with courage as they grow older. Self-esteem can be threatened by the idealization of figures in the media or advertisements that tell children that if they use a different product or change something about their appearance they will be better people. According to this study, nature provides a self-esteem booster and may provide a way for schools to counteract some of the negative self-imagery that children receive from the media. In addition, increased self-esteem may lead to increased test taking abilities of students.

Spending time outdoors during school is also beneficial to students with kinesthetic learning styles and seems to help "[...] boys in particular, reach their potential," (Swarbrick, 2004). Outdoor education can lend itself more readily to the needs of many different types of children and help them learn due to its engagement of multiple senses and physical engagement 
OUTDOOR TIME IN PORTLAND ELEMENTARY SCHOOLS

and interaction with other species. Howard Gardner's theory of multiple intelligences includes naturalistic learners who are, "Often interested in nurturing and exploring our environment, [...] [and] highly aware of even subtle changes to their surroundings," (Randall, 2012). Spending time outdoors supports the naturalistic learner's ability to reach their full potential and contribute to society because, "Which intelligences thrive and grow depends on what is valued and nurtured by those around us," (Randall, 2012).

Similarly, traditionally 'bad-learners' or 'bad-children' may do better in school if they are put in an environment that is more receptive of their actions. Nature responds to our actions in a form that is non-judgmental. The 2004 Swarbrick study found that forest education increases "[...] confidence, and positive participation from disruptive children." School can have great effects on self-esteem and confidence, especially for children who consistently fail. "The Executive Summary of Excellence and Enjoyment (DfES, 2003) states that, 'Primary education is about children experiencing the joy of discovery, solving problems, being creative, developing self-confidence as learners and maturing socially and emotionally' - all central themes of the forest school projects," (Swarbrick, 2004). Forest school education is conducive to the learning environment if there green space is accessible to the students as well as teacher interest.

"He [Richard Louv] coined the term 'nature-deficit disorder' to describe the human costs of alienation from nature listing: diminished use of senses, attention difficulties, and higher rates of physical and emotional illness," (Randall, 2012). The 2011 study Swiss Elementary School Teachers' Attitudes Towards Forest Education by Petra Lindemann-Matthies and Sarah Knecht responds to Richard Louv's concept of "nature-deficient disorder" with a study of 15 Swiss elementary school teachers and their experiences and attitudes toward forest education. Forest education is education conducted in an outdoor setting and "the use of forests as an outdoor 
OUTDOOR TIME IN PORTLAND ELEMENTARY SCHOOLS

classroom is becoming increasingly popular in European countries," (Lindemann-Matthies, 2011). The study found that students were more focused, open, and social in the forest. All of these qualities are encouraged in a school setting where children are prepared for adulthood and learn to interact with other people and the world around them. This study contributes to the field of environmental health because it describes a relationship between school and nature and the effects of nature on child behavior. The study found that, "teachers who learned about forest education during pre-service education were more likely to conduct it." This suggests that forest education, or any type of training regarding ways to educate children outdoors, should be incorporated into teacher training if schools want teachers to take their classes outdoors more often. The study also found that "Bad weather, parents, the educational system, and the workload were no obstacles to forest education, nor was the forest perceived as more dangerous than the classroom or schoolyard.” This suggests that 'bad weather,' or the Portland rain, is not an obstacle to incorporating forest education or more outdoor time in Portland schools. The study found that maintaining discipline and rituals were important to teachers and that "setting clear rules was regarded as important." Outdoor education trainings may lead instructors to be more inclined to take their students outdoors and provide children with the benefits of spending time outdoors during school.

Spending time in nature acts as a buffer to children's vulnerability to stress. A 2003 study by Wells found that "the impact of stressful events on psychological distress is weaker under conditions of high nature than under low nature conditions." Children who spend more time outdoors during school are better able to psychologically deal with stressful events, but those with the highest levels of stress have less opportunities to go outdoors due to shortened or eliminated recess time. A 2008 examination of elementary school recess trends since the 
OUTDOOR TIME IN PORTLAND ELEMENTARY SCHOOLS

enactment of No Child Left Behind found that, "While most children, regardless of location, continue to get recess on a regular basis, children who attend high-minority, high-poverty, or urban [elementary] schools are far more likely than other children to get no recess at all," (Barth, 2008). Because socioeconomic status correlates to academic achievement, children who attend high-poverty schools are already at a disadvantage in their ability to succeed in school, and a lack of outdoor time at recess only amplifies this problem (Sirin, 2005).

Socioeconomic status is an important factor in determining child health and development, as well as their ability to succeed. In their article Why poor children are more likely to become poor readers: The school years, Buckingham, Wheldall, \& Beaman-Wheldall state that, "Socioeconomic status at the individual- and school-level are positively related to literacy achievement in all English-speaking countries," (2013). They also note that, "A socioeconomic gradient to child health has been found in numerous studies; child health scores decline with SES." And, "The AEDI [Australian Early Development Index] shows that the proportion of children assessed as developmentally vulnerable on the 'emotional maturity' domain (which includes sociability, anxiety, aggression, hyperactivity and inattention) increased as SES decreased," (Buckingham, Wheldall, \& Beaman-Wheldall, 2013). Low SES is linked to poor literacy, poor health, and behavior problems. Based on the evidence that nature has a positive effect on health and behavior, children of lower SES may benefit from more time outdoors.

As our society spends less time outdoors, our use of antipsychotic drugs has increased. Louv notes that "between 2000 and 2003 there was a 49 percent increase in the use of psychotropic drugs-antipsychotics, benzodiazepines, and antidepressants. [...] Although exposure to nature may have no impact on the most severe depressions, we do know that nature experiences can relieve some of the everyday pressures that may lead to childhood depression," 
OUTDOOR TIME IN PORTLAND ELEMENTARY SCHOOLS

(Louv, 2008). He mentions, "in The Human Relationship with Nature, Peter Kahn points to the findings of over one hundred studies that confirm that one of the main benefits of spending time in nature is stress reduction," (Louv, 2008). Louv suggests that children who are deprived of time in nature are also deprived of a coping mechanism for depression. Taking children outdoors during the school day is an inexpensive way for Portland elementary schools to help reduce or prevent childhood depression and the growing need for psychotropic drugs.

Outdoor education can provide children a sense of self and help them create their own identity. Ruth Wilson, in her article Becoming whole: Developing an ecological identity, describes how outdoor education allows teachers to give children the chance to develop an “ecological self [...] described as an individual's connections with and attitudes toward the natural environment. She notes that "the child with a positive ecological identity has a sense of belonging in knowing that he or she is a part of nature versus separate from it, a sense of wonder in being in touch with what is beautiful and awe-inspiring in the natural world, and a sense of security [...]." She lists eight ways in which "teachers can promote a positive ecological self in young children" and many involve physically spending time outdoors. Children are a part of the world around them, but the connections to the world and a greater understanding of our interconnectedness and dependence on nature, may be difficult for children to understand without being able to spend time outdoors and observe nature. The responsibility of educators, and the need for schools to provide children with outdoor experiences, is increasing as urbanization increases and children spend more time in the virtual world of technology (Wilson 2011). Without access to the outdoors as a child, an adult may have an impaired ability to lead a healthy lifestyle because so much of our physical and mental health is dependent on the world around us and our connection to nature (Louv, 2011). 
OUTDOOR TIME IN PORTLAND ELEMENTARY SCHOOLS

Evidence regarding Wilderness Therapy suggests that nature helps prepare people to make positive life decisions. Wilderness Therapy allows clients to learn how to cope with life's problems by practicing solving problems in the wilderness, where the environment provides natural consequences to clients' choices (Hill, 2007). In his study of Wilderness Therapy as a Treatment Modality for At-Risk Youth, Hill discusses the importance of group therapy and reflection in nature. Hill describes Wilderness Therapy as a treatment option for youth who are at risk for mental illness and finds that it empowers youth by focusing on "the attainment of physical trust before the development of emotional trust".

In an article for the Nature Action Collaborative for Children, Wilson describes the importance of positive relationships for child development. She states that, "An emotionallyhealthy child has a positive relationship with self, in that he or she views self in a positive way. A socially-healthy child has positive relationships with others, including peers and adults in a diverse society. An ecologically-healthy child has a positive relationship with nature which includes understanding, appreciating, and respecting the natural world and his or her place in this world," (Wilson, 2011). Numerous studies and literature suggest that spending time outdoors contributes positively to each of these relationships and has a positive effect on academic achievement (Jarrett, 2013; Lindemann-Matthies, 2011; Louv, 2008; Sallis, 1999; Swarbrick 2004; Wells, 2003). In R. S. Ulrich's proceedings of the $2^{\text {nd }}$ Annual International Congress on Design and Health, June 2000, as cited in Randall, 2012, “There is a strong body of research confirming that direct contact with nature increases mental health and psychological and spiritual development. Benefits include stress reduction, a sense of coherence and belonging, improved self-confidence and self-discipline, and a broader sense of community," (Randall, 2012). Selfconfidence, self-discipline, and a sense of community are all fundamental traits for schools to 
OUTDOOR TIME IN PORTLAND ELEMENTARY SCHOOLS

cultivate in children, in order to prepare them, "to make productive life decisions," (Portland Public Schools - About Portland Public Schools, 2014).

Recess is the only time of the school day which is scheduled daily outdoor time. According to the PPS website, most of the elementary school recesses are 20-35 minutes long and are scheduled once during the school day for $\mathrm{K}-5^{\text {th }}$ graders (although many teachers can take their classes outdoors at their own discretion) (Portland Public Schools, 2013). According to my research presented in Appendix A, children receive the most amount of time outdoors at school during recess (as long as recess is not held indoors). "[...] since the enactment of NCLB [No Child Left Behind Act], 20\% of U.S. school systems decreased recess time, averaging recess cuts of 50 minutes per week," (Jarrett, 2013). Recess contributes positively to children's health, development, and ability to be successful learners, due to the benefits of being outdoors, the opportunity for children to play freely, and the greatest opportunity during the school day for children to be physically active (Jarrett, 2013). Children who have less recess are at greater risk for inactivity due to decreased outdoor time and decreased opportunity for physical activity. "Experimental research has found that children were less active after school on days when they had no recess and PE classes in school, suggesting that inactivity breeds inactivity," (Jarrett, 2013). Unfortunately, there is inequity in the amount of recess, if any, that children receive. A 2002 U.S. national sample of elementary school teachers, "found that $79 \%$ had recess. But only $61 \%$ of the African American students and $75 \%$ of other minority students had recess compared to $85 \%$ of white students. Also, only $56 \%$ of those living below the poverty line had recess compared to $83 \%$ of those above the poverty line," and "Although cause and effect cannot be assumed, the ethnic groups with the highest incidence of childhood obesity are also the groups least likely to get recess," (Jarrett, 2013). This study examines inequities in the amount of recess 
OUTDOOR TIME IN PORTLAND ELEMENTARY SCHOOLS

and time spent outdoors in Portland public elementary schools. This review of the current literature suggests that students at schools with less outdoor time are at a disadvantage with regards to development of social skills, ability to concentrate, ability to handle stress, and the opportunity to be physically healthy.

The Portland public school district performance auditor defines instructional time as, “The number of hours students spend in class - 'seat time'. Instructional time does not include lunch, recess, or other non-instructional activities," (Tracy, 2007). Schools receive pressure to increase instructional time yet 'seat time' disregards all of the learning and physical and social development that occurs when children are not in their seats, when they are outdoors running around. Although schools are under pressure to increase instructional time, which does not include recess, a "2-year health-related school physical education program on standardized academic achievement scores [...] assessed in 759 children" found that "Despite devoting twice as many minutes per week to physical education as Controls, the health-related physical education program did not interfere with academic achievement. Health-related physical education may have favorable effects on students' academic achievement," (Sallis, 1999). This evidence suggests that recess should be included as 'instructional time' due to its possible favorable effects on students' academic achievement. Finnish schools provide an example of the correlation between outdoor time and academic achievement. "Finland topped a respected international survey last year, coming in first in literacy and placing in the top five in math and science. [...] [At] The Suutarila school [...] typical of Finnish 'comprehensive schools,' which run from first to ninth grade [...] After every 45-minute lesson, they [the students] are let loose outside for 15 minutes so they can burn off steam," (Alvarez, 2004). This evidence suggests that the addition of more outdoor breaks throughout the school day may enhance academic 
OUTDOOR TIME IN PORTLAND ELEMENTARY SCHOOLS

achievement, although other variables may affect this correlation, such as culture and socioeconomic status.

In Last Child in the Woods Louv quotes James Sallis who, "For years, [...] has been studying why some children and adults are more active than others. [...] 'Based on previous studies, we can definitely say that our best predictor of preschool children's physical activity is simply being outdoors,' says Sallis, 'and that an indoor, sedentary childhood is linked to mentalhealth problems," (Louv, 2008). Sallis' research provides evidence that outdoor time is beneficial to healthy child development and that disparities between the amounts of time that children spend outdoors could have long term consequences for their health.

Current research suggests that recess and outdoor time is optimal when conducted in a natural environment. Adam Bienenstock, in his article Making the Case for Natural Playgrounds, argues that, "By adding nature to your playground, the 'A' type child naturally calms down and collaborates. The other $60 \%$ have an activity that they can excel at while enhancing their gross and fine motor skills at their own pace," (2010). He mentions, "A study by Danner in 1991 showed that as much as 60\% of unsupervised children in a traditional playground are completely sedentary. Fjortoft and Sageie's playground study in 2004 showed a direct positive correlation between the number of natural features (trees, hills, grass, sand, water, et cetera) and the amount of gross motor activity with children," (Bienenstock, 2010).

Bienenstock suggests that outdoor time is optimal for child health and development when nature is included in the playground. This suggests that Portland elementary schools with more natural features in their playgrounds provide students with the most benefits when their students spend time outdoors. 
OUTDOOR TIME IN PORTLAND ELEMENTARY SCHOOLS

The outdoor classroom offers instructors the opportunity to include outdoor time as 'instructional time' while still obtaining the benefits of the outdoors on child learning and development. "As a mini-ecosystem, the 'outdoor classroom' fosters the use of systems thinking and emphasizes the interconnectedness of all things. Through exposure to the intricate web of life, students come to understand that complex natural and societal systems often require holistic rather than linear solutions. [...] Integrating the use of outdoor learning into the curriculum begins to balance digital learning and starts to cure nature deficit disorder," (Randall, 2012). Randall also suggests that, "Emersion in the outdoors makes learning a multi-sensory experience. By engaging in senses of touch, smell, hearing, taste, and seeing, students retain an intimate physical memory of activities that are long lasting and synergistic," (2012). Spending time outdoors during school allows children to develop and strengthen more of their senses as well as improve concentration.

Portland is a metropolitan area and most children in Portland do not have as much access to the outdoors as rural children. "In an urban setting, where barren treeless spaces are more common and the amount of nature is more variable, it is possible that nature might play a stronger role as a moderator of stress or adversity," (Wells, 2003). For this reason, it is partly the responsibility of the city and the school system to ensure that the children of Portland receive access to outdoor learning to "increases attention span, enhances memory, reduces stress, improves mood and opens the mind to greater activity," (Randall, 2012). The goal of Portland Public Schools is that: "By the end of elementary, middle and high school, every student by name will meet or exceed academic standards and will be fully prepared to make productive life decisions," (Portland Public Schools, 2014). The studies and articles presented in this literature review that discuss the positive correlation between spending time outdoors and child 
OUTDOOR TIME IN PORTLAND ELEMENTARY SCHOOLS

development, health and ability to handle stress, suggest that outdoor education is necessary in order to achieve the goal of Portland Public Schools. Improved self-esteem, social skills, ability to focus and imagination of children who attend forest schools in the above studies, are all qualities that are important in achieving the goal of preparing children "to make productive life decisions," (Portland Public Schools, 2014; Lindemann-Matthies, 2011, Swarbrick, 2004).

Although Oregon has no state policy regarding general physical activity requirements, recess, physical activity breaks or recess before lunch, most Portland public elementary schools provide their students with recess and PE, and have other programs to get kids outdoors and allow them to learn about and experience nature (Physical Activity Other Than Physical Education, 2013; Portland Public Schools - About Portland Public Schools, 2014). Many Portland elementary schools have a school garden. For example, the Garden of Wonders is an outdoor garden where the children of Abernathy Elementary School learn about nature, food, science, and cooking. The food from the garden is used daily in the cafeteria's school lunches. There are also summer camps at the garden where children learn about the Earth, gardening, and how to prepare food. The Garden of Wonders website states that, "school gardens, significantly increase science achievement scores, improve social skills and behavior, improve environmental attitudes, $[\ldots]$ instill appreciation and respect for nature that lasts into adulthood, improve life skills, including working with groups and self-understanding, contribute to communication of knowledge and emotions, while developing skills that will help them be more successful in school, and have a positive impact on student achievement and behavior." The school garden provides a space where children can connect with nature and learn in a different way than they would in the classroom. According to the Garden of Wonders website, the garden is supported by, and has grown, due to strong parent and teacher support. This garden provides an example of 
OUTDOOR TIME IN PORTLAND ELEMENTARY SCHOOLS

a way that schools can incorporate outdoor education into the curriculum and how children can be included in every part of the food growing, harvesting, and cooking process. The children of Abernathy School get to see their food grow, help prepare it, and learn the importance of fresh and local fruits and vegetables. According to the Garden of Wonders website, the Portland Public School Nutrition Services even said that, "The award-winning Abernethy model is now ready to be taken to scale if additional resources are made available. A district-wide pilot program will instruct and inspire institutionalization of farm-to-school concepts across Oregon and the country" (Gardenofwonders.org).

Garden work is a way to connect humans to where we come from (our body depends upon the consumption of food that grows in the Earth) and also connect us to where our body will go upon death. Being in nature may also have the power to connect us to the Earth and engage us in the flow of energy and life. A 2007 study conducted by Parr examines the therapeutic value of nature work (in manicured gardens) and its relationship between the mental health of individuals with mild to severe mental illness. The article discusses two urban garden projects (Ecoworks and the Coach House) where individuals with mental illness volunteer their time to work in a garden. It includes excerpts from both staff and volunteers. The study concludes that garden work is "a sustainable vehicle for new versions of social citizenship for people traditionally marginalized in mainstream society," (Parr, 2007). The study emphasizes the importance of social inclusion, and school garden work provides an opportunity for all students to feel included in a project.

Atkinson Elementary School and Sunnyside Elementary School also have outdoor gardens and classrooms, among other Portland schools. "The Sunnyside gardens feature a wide variety of native, ornamental and edible species, including vegetable beds designated for each 
OUTDOOR TIME IN PORTLAND ELEMENTARY SCHOOLS

grade. The gardens serve as outdoor learning environments throughout the year, integrating a variety of academic subjects including art, math, history, social sciences, and natural sciences," (Portland Public Schools, 2014). All of these gardens embody the goal of Portland Public Schools and, according to the studies and research presented above, the school gardens improve and encourage healthy development of the children that work, learn, and play in this environment.

\section{Methodology}

This study examines inequalities in the amount of outdoor time between Portland elementary schools and its relationship to socioeconomic status. For the purposes of this study "outdoor time" is defined as the percentage of the school day spent at recess. Although recess is not always spent outdoors, and students may perform other activities outside during the school day, recess was chosen to represent outdoor time due to its consistency between schools and its ability to be measured in minutes. Socioeconomic status was measured as the percentage of students at each school who receive free or reduced price lunch. Schools with a higher percentage of students who receive free or reduced lunch are considered lower socioeconomic status than schools with a lower percentage of students who receive free or reduced lunch. Schools with a low percentage of students receiving free or reduced price lunch are considered more affluent and are considered higher socioeconomic status. Data regarding recess, PE, field trips, socioeconomic status, and school gardens was collected and analyzed for fifty-eight Portland public elementary schools.

Preliminary information, books, and articles regarding outdoor education and its relationship to children's health were obtained from the Portland State University library database by performing key word searches including the words outdoor time, recess, education, 
OUTDOOR TIME IN PORTLAND ELEMENTARY SCHOOLS

nature schools, health, and outdoor education. After examining two key sources, The Nature

Principle and Last Child in the Woods by Richard Louv, a Google Scholar search was performed to identify articles that have cited these two works. Articles from the fields of education, public health, environmental health, psychology, and child development were examined. After performing the key word searches, additional resources were gathered by examining works that were cited by the articles found on the Portland State University library database.

Data regarding outdoor time and outdoor opportunities at Portland public elementary schools was gathered from the sixty-one elementary schools listed on the Portland Public Schools website (http://www.pps.k12.or.us/). Three of these elementary schools were not included in the study due to insufficient data. The socioeconomic status of each school was determined from data regarding the percentage of students at each school who receive free and reduced price lunch, listed on the October 2013 Portland Public Schools Enrollment Characteristics (October 1, 2013 Enrollment - Summary Comparison, Retrieved January 19, 2014). The socioeconomic status of each school was measured as the percentage of students receiving free and reduced price lunch and the schools were divided into four groups: $<25 \%, 25$ $50 \%, 51-75 \%,>75 \%$.

Information regarding school outdoor time was gathered by calling the schools and asking for information regarding the frequency and duration of recess, PE, and school garden time. In order to acquire further information regarding the amount of time spent outside and outdoor opportunities provided in the classroom, a representative group of forty teachers were contacted via email. Five schools from each of the socioeconomic status groups were chosen at random, and two randomly chosen teachers from each of these schools (one $\mathrm{K}-2^{\text {nd }}$ grade teacher and one $3^{\text {rd }}-5^{\text {th }}$ grade teacher) were sent an email which included the following two questions: 
OUTDOOR TIME IN PORTLAND ELEMENTARY SCHOOLS

1) Approximately how often do you take your students outside each week? (How many times and for how long?)

2) What types of outdoor opportunities do you provide your students? (Please include field trips, outdoor school, garden work, outdoor play breaks, etc.)

A follow-up email was sent to the teachers who failed to respond to the first email after ten days.

Outdoor time was measured as the percentage of the school day spent outside at recess. Further data regarding PE, school gardens, and field trips, as well as personal responses from teachers, were also examined and discussed. A scatterplot graph of outdoor time versus the socioeconomic status of each school was created to analyze the data, and a line of best fit and $\mathrm{R}^{2}$ value were used to determine the relationship between outdoor time and socioeconomic status of Portland public elementary schools.

\section{Results}

Table 1 displays the data collected regarding length of school day, length of recess, additional outdoor opportunities (PE and school gardens), and percentage of students receiving free or reduced price lunch for fifty-eight of the sixty-one Portland public elementary schools (see Appendix A). This results in a 95\% response rate. The schools MLC, Abernethy, and Odyssey at Hayhurst, were not included in the data table due to insufficient data. Eight of the forty representative teachers who were sent an email survey, responded with information regarding outdoor time specific to their students, resulting in a $20 \%$ response rate for additional data. These responses are included as additional data and can be found in Appendix B. 
OUTDOOR TIME IN PORTLAND ELEMENTARY SCHOOLS

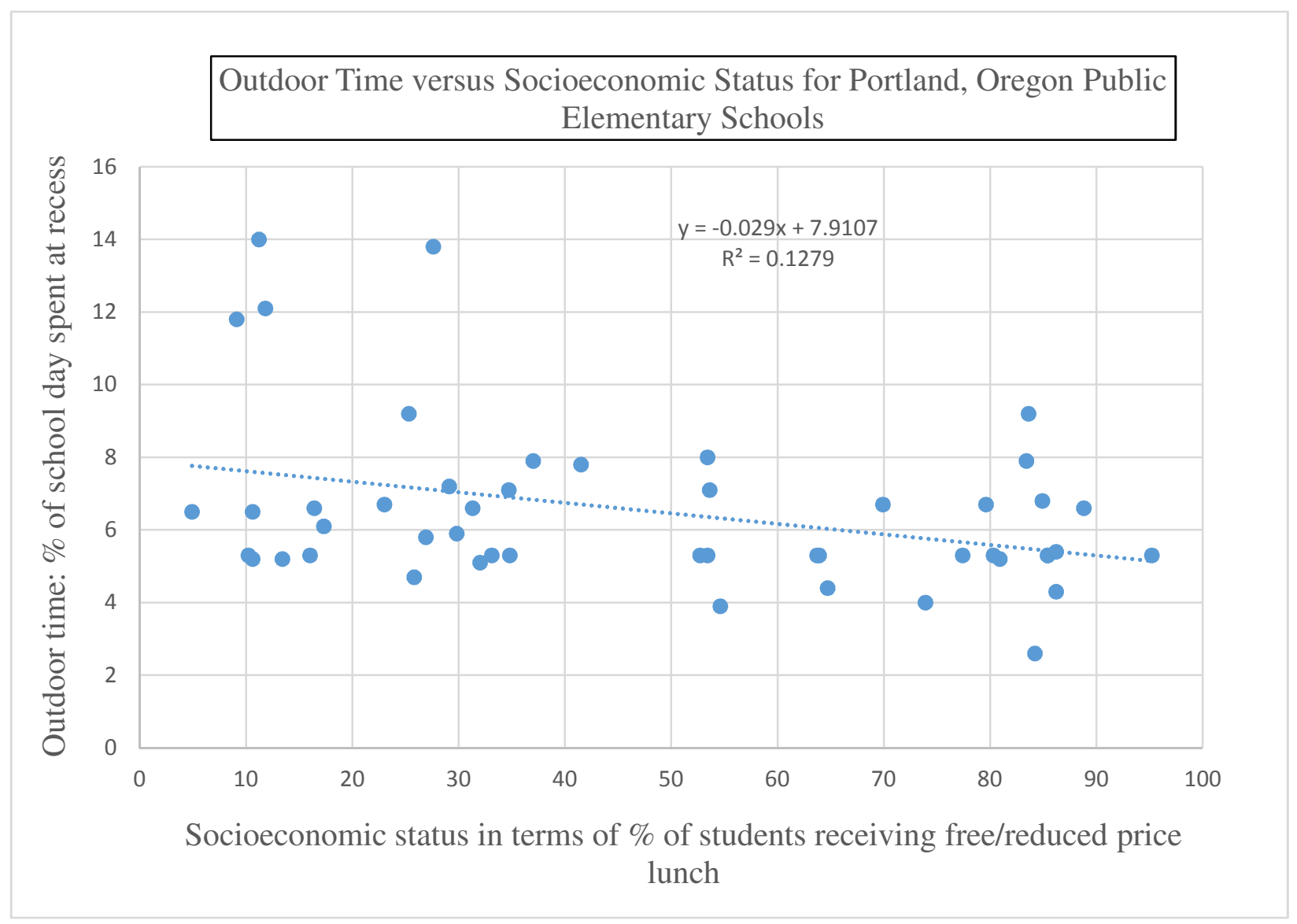

Figure 1. Outdoor time versus socioeconomic status of Portland public elementary schools

Fig. 1 depicts the correlation between outdoor time and socioeconomic status of Portland public elementary schools. The trend line depicts a negative slope which indicates that outdoor time, represented by the percentage of the school day spent at recess, tends to decrease as the percentage of students receiving free or reduced price lunch increases and socioeconomic status decreases. In other words, the schools with less students who receive free or reduced price lunch tend to spend more time at recess than do the schools with a higher percentage of students who receive free or reduced price lunch. The $\mathrm{R}^{2}$ value of 0.1279 indicates that, although there is some 
OUTDOOR TIME IN PORTLAND ELEMENTARY SCHOOLS

variability in the data, the model explains some of the variability in the data and there is a small correlation between the variables.

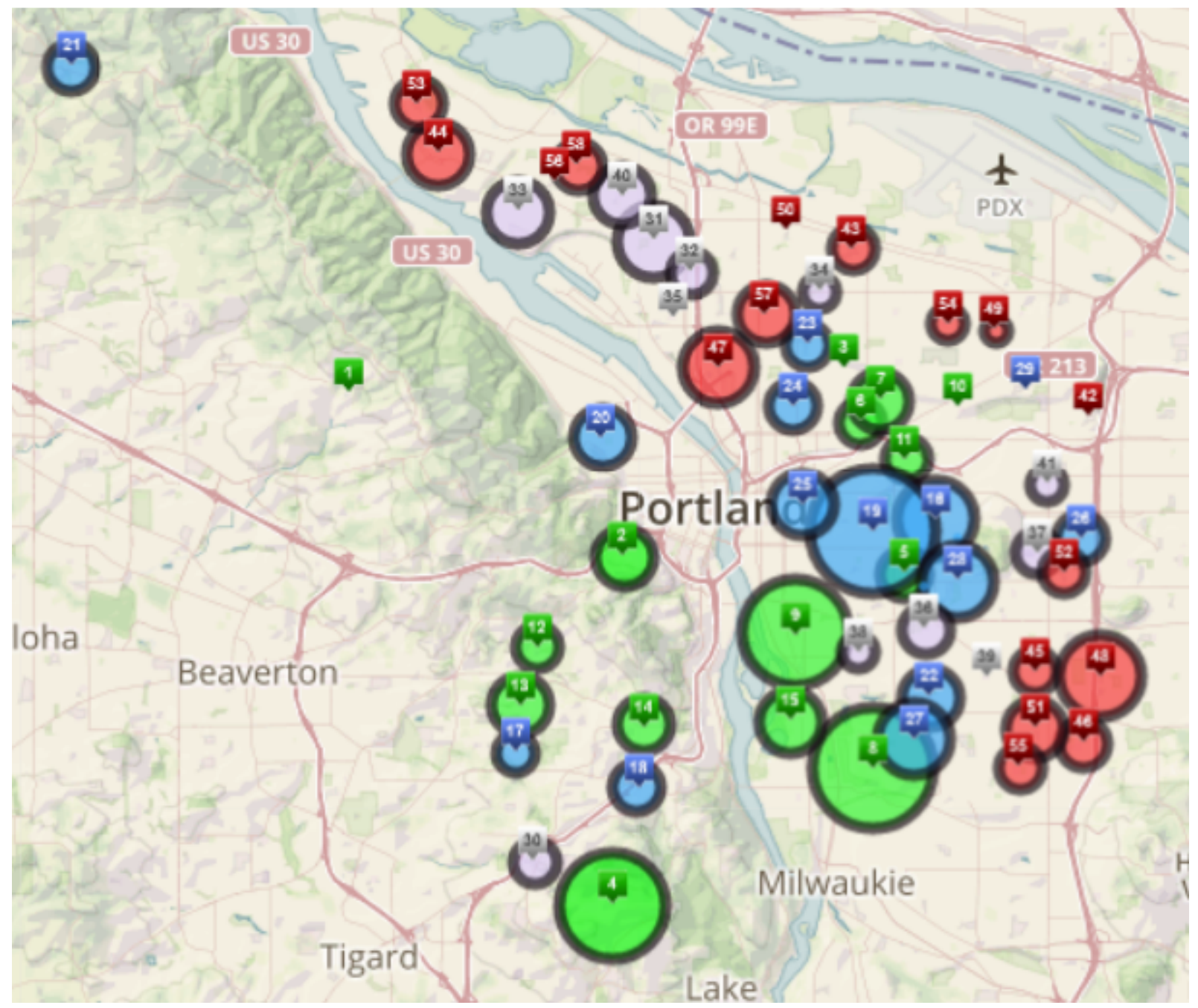

Figure 2. Location, socioeconomic status, and outdoor time of Portland public elementary schools

Fig. 2 depicts the physical location, socioeconomic status, and amount of outdoor time of Portland public elementary schools. The number on each point on the map corresponds to the school's number on the data table in Appendix A. Schools are ranked from high (\#1) to low (\#58) socioeconomic status. The colors represent socioeconomic status. $<25 \%$ of students at 
OUTDOOR TIME IN PORTLAND ELEMENTARY SCHOOLS

green schools receive free or reduced price lunch (corresponds to higher socioeconomic status), $25-50 \%$ of students at blue schools receive free or reduced price lunch, $51-75 \%$ of students at white schools receive free or reduced price lunch, and $>75 \%$ of students at red schools receive free or reduced price lunch (corresponds to lower socioeconomic status). The radius of the circle around each school correlates to the amount of outdoor time at the school: the bigger the circle, the higher the percentage of the school day is spent at recess. Schools about which no outdoor time data was available are represented by a numbered point on the map but lack a circle. The lowest SES schools tend to be located in NE and on the outskirts of SE Portland. The schools with the most outdoor time tend to be green and blue, suggesting that schools with higher socioeconomic status (less than half of the students receive free or reduced price lunch) receive more outdoor time. Although socioeconomic status differences clearly occur in different parts of Portland, the variability in outdoor time is more difficult to identify in the representation on the map.

The survey responses did not reveal any significant trend but were supportive of the data in Table 1. Responses were received from at least one school in every socioeconomic group except for the schools with $>75 \%$ of students receiving free and reduced price lunch. Five of the eight teachers who responded reported taking their classes on field trips throughout the year and four of the schools reported using the school garden. Two schools with 51-75\% of students on free and reduced price lunch and one school with $<25 \%$ of students on free and reduced price lunch did not report any field trips. Four of the eight teachers reported that their class spends time outside in the school garden.

\section{Discussion}


OUTDOOR TIME IN PORTLAND ELEMENTARY SCHOOLS

The results of this study indicate that there is a correlation between socioeconomic status and outdoor time at Portland public elementary schools. The results are consistent with my hypothesis. The primary finding is that higher socioeconomic status public elementary schools in Portland spend more time outdoors during the school day than do lower socioeconomic status schools. Despite the low R-squared value of 0.1279 , there is a visibly significant downward trend to Fig. 1. The additional data regarding PE also supports my hypothesis because schools in the lowest socioeconomic status group tend to only have PE once per week while higher socioeconomic status schools have PE twice per week (see Appendix A). However, one of the limitations of this study is that recess and PE may not always be held outdoors. Another limitation of this study is that reporting may be inaccurate, as most of the data was collected from phone conversations with school office staff. Several office staff stated that additional recesses are up to the teacher's discretion suggesting additional variability to the data, as well as variability between classrooms at the same school. Inaccurate reporting is the most significant limitation to the study. Another limitation to this study is a lack of individual teacher contact. Additional resources to contact more teachers individually regarding outdoor time are needed in order to obtain more accurate data.

The data suggests that there is inequality between schools regarding outdoor time. Students at schools with less outdoor time may be at a disadvantage for their ability to learn and develop physical, social, and mental well-being. This proposition is based on previous studies and research presented in my literature review which demonstrate the positive relationship between outdoor time, education, child development and health (Jarrett, 2013; LindemannMatthies, 2011; Louv, 2008; Sallis, 1999; Swarbrick 2004; Wells, 2003). This is consistent with a 2008 review of recess trends regarding information from the Centers for Disease Control and 
OUTDOOR TIME IN PORTLAND ELEMENTARY SCHOOLS

Prevention. In his review, Barth states that "the Centers for Disease Control and Prevention

(CDC) [found that], as recently as $2006,96.8$ percent of elementary schools still had regularly

scheduled recess in at least one grade, and the average allotted time was 30.2 minutes per day

(Lee et al 2007). [...] [but] the pressure on schools to find more instructional time is real, and it seems to be leading many districts to shave minutes from the recess time they provide. In addition, children who attend high-poverty, high-minority, or urban schools are far more likely than their peers in other locations to get no recess at all—a definite 'recess gap' that commands our attention," (2008). The pressure to find more instructional time is reflected in the teacher responses to the email survey. One instructor stated that, "my class gets an additional 4060 minutes per week of outside freedom. I will tell you, though, that taking extra breaks is actually looked down upon because it is believed that it takes away from 'instructional time'," (Beverly Cleary Elementary School at Fernwood Campus, $3^{\text {rd }}$ grade, 2014). All of the Portland public elementary schools included in this study provide students with a lunch recess. Most other recesses or breaks are up to the teacher's discretion (see Appendix A). Although some instructors take their students out for additional recesses, the majority of email survey responses indicate that students go outdoors for recess less than 30 minutes per day. One instructor stated that, "My students have recess daily. Two times throughout the day. Lunch recess and an afternoon recess. Lunch recess is $20 \mathrm{~min}$ and same for afternoon recess. It is important they always get a break," (Duniway Elementary School, $4^{\text {th }}$ grade, 2014). The body of research presented in the literature review suggests that these breaks may be undervalued by Portland Public Schools and that breaks offer a valuable opportunity for children to learn, activate their senses, and play outdoors without "interfere[ing] with academic achievement," (Sallis, 1999). 
OUTDOOR TIME IN PORTLAND ELEMENTARY SCHOOLS

The map in Fig. 2 examines the data in regards to physical location of the schools in Portland. There is a distinct difference in the location of schools with over $50 \%$ of the students who receive free and reduced price lunch and schools with less than $50 \%$ of the students who receive free and reduced price lunch. Schools in NE and Far East Portland tend to be of lower socioeconomic status. Socioeconomic status correlates positively to academic achievement suggesting that lower SES students schools that have less outdoor time are at an even greater disadvantage compared to students at schools with more outdoor time (Sirin, 2005).

The schools with less outdoor time may be at a further disadvantage if they are located in areas of Portland where there is less access to green space and public parks. The negative effects of a lack of outdoor time for students may be exacerbated if the students also live in an area in which they are unable to spend time outdoors after school. Students of low SES are most vulnerable to the disadvantages that a lack of outdoor time provides due to the higher stress that impoverished communities face and the increased prevalence of childhood obesity (Jarrett, 2013; Wells, 2003). Students who live in areas of Portland that lack access to green space may benefit from extra outdoor time during school and several studies have examined ways in which outdoor time can be added to enhance student success.

"A simple first step can be to literally move the classroom outdoors. Just being in nature through passive absorption, feeling the breeze, listening to the birds, our attention span enlarges. Stress levels lower and we can focus even on a traditional lecture delivery more easily," (Randall, 2012). If teachers were provided with more information and training regarding the benefits of outdoor education to child development and achievement, they might be more inclined to take their classes outdoors. A 2011 study by Flom, B., Johnson, C., Hubbard, J., \& Reidt, D., found that, "School counselors are also well positioned to offer school wide preventive 
OUTDOOR TIME IN PORTLAND ELEMENTARY SCHOOLS

programming for building healthful outdoor opportunities. By partnering with parent

organizations, school administrators, and teachers, counselors can support local implementation of national programs such as National TV Turnoff Week [...], International Walk to School Day [...], various schoolyard habitat certification programs, and school garden projects."

Half of the teachers who responded to the email survey indicated that they take their students outdoors to a school garden but only two teachers mentioned taking their students outdoors for class. A $2^{\text {nd }}$ grade teacher at Bridger Elementary School stated that, "We also use the school garden as needed to do science, usually once a week from April-June. They also work in the garden $[\ldots]$ one hour once a month.” Although trends and correlations regarding school gardens and socioeconomic status are not examined in this study, "School gardens have been found to significantly benefit children's social and academic development, but may not be equally available to all children. [...] Results from our statistical analyses show that school gardens in SCC [Santa Clara County] are more likely to exist in economically stronger and ethnically less-diverse neighborhoods," (Stewart, I., Purner, E., \& Guzmán, D., 2013). Further research regarding the distribution of school gardens and the amount of time that students spend using gardens in Portland elementary schools may reveal correlations similar to those of Santa Clara County.

During the collection of data for this study, several sources mentioned that students spend time outdoors during Playworks (see Appendices A and B). Playworks provides students with a structured recess (Mallonee, 2011). Studies regarding Playworks found that, "Playworks promoted an organized and structured recess by teaching students a variety of games, tools for conflict resolution, inclusive language and positive messaging, all of which reportedly led to improved student engagement and reductions in conflict at recess. Teachers and principals linked 
OUTDOOR TIME IN PORTLAND ELEMENTARY SCHOOLS

these changes to a physically and emotionally safer recess environment for students," (Mallonee, 2011). Playworks leads teachers to be more inclined to take their students outdoors to recess because, "as three-quarters reported in the teacher survey, Playworks reduced their stress levels while on yard duty," (Mallonee, 2011). As of 2010, the Portland public schools with Playworks coaches were Bridger, Grout, King, Jason Lee, Markham, Rigler, Rosa Parks, Sitton, and Woodlawn, but the program has since expanded (Pulse: New recess program keeps the peace). A $3^{\text {rd }}$ grade teacher at Vestal Elementary School stated that, "My students get 15 minutes a day of recess that I supervise and then about 10 minutes of lunch recess. [...] We do have Playworks at our school and my class gets 30 minutes of game instruction each week. So far this has been outside but it will be in the classroom when we cannot go outside." More training and information for teachers regarding the benefits of outdoor time for children, as well as the expansion of programs such as school gardens and Playworks, could lead to improvements in confidence, social skills, conflict resolution, self-esteem, mental, and physical health and help prepare children "to make productive life decisions," especially among low SES schools.

The socioeconomic disparities in the provision of outdoor time in Portland, Oregon public elementary schools demonstrates an inequity that is not only an education issue, but also a public health concern. The results of this study indicate that students at schools of lower socioeconomic status spend less time outdoors during school and thus miss out on the numerous benefits that outdoor education provides.

More credible data regarding outdoor time are necessary to address the limitations presented in this study. More classroom and teacher specific data are needed to develop a more accurate measurement of the amount of time spent outdoors at different schools. Future studies may want to collect more accurate data regarding outdoor time by addressing the limitations of 
OUTDOOR TIME IN PORTLAND ELEMENTARY SCHOOLS

this study such as time spent at outdoor recess rather than indoor recess and the time spent outdoors during PE, field trips, and in school gardens. Future studies might examine the relationship between the amount of outdoor time offered at schools and the accessibility to green space for the students that attend each school, as well as the feasibility for students to spend time outdoors while outside of school. Data regarding the academic success, and physical, social and mental health and development of Portland public elementary school children would be beneficial in examining the effects of outdoor time on Portland public elementary school children and determining whether there is a correlation between outdoor time and child health and development. After reviewing the current literature regarding outdoor time and socioeconomic status, there is little longitudinal research that examines the long-term effects of childhood outdoor time deprivation. Longitudinal studies that examine the differences between development and health in children that spend different amount of time outdoors during school would provide more comprehensive data regarding the impact of outdoor time during school on the development of a child and its impact on their social, mental, and physical health throughout their lifetime.

\section{Conclusion}

The results of this study indicate that higher socioeconomic status elementary schools spend more time outdoors than low SES schools in Portland, Oregon. A review of the current literature found that time spent outdoors, especially in a natural setting, has a positive effect on children's social skills, ability to concentrate, self-esteem, health, and development, whereas low SES is linked to poor literacy, poor health, and behavior problems. Because socioeconomic status correlates to academic achievement, children who attend high-poverty schools are already at a disadvantage, and a lack of outdoor time amplifies this problem. Hopefully, as teachers, administrators, and the public become more aware of the benefits of outdoor time to child health 
OUTDOOR TIME IN PORTLAND ELEMENTARY SCHOOLS

and development, they will increase training and support for teachers to take their classes outdoors. This thesis raises the questions: why are impoverished Portland children less likely to spend time outdoors than more affluent Portland children? And how can the Portland community support teachers and help schools provide students more opportunities to go outside during the school day, especially among low SES schools? Although more comprehensive and credible data is necessary, this thesis provides preliminary evidence that there is inequity between Portland elementary schools in regards to outdoor time. This study proposes that the Portland public school system address the inequity regarding school outdoor time and its relationship with socioeconomic status, in order to regain equity between schools and achieve its goal for every student to, “[...] meet or exceed academic standards and [...] be fully prepared to make productive life decisions," (Portland Public Schools - About Portland Public Schools, 2014). 
OUTDOOR TIME IN PORTLAND ELEMENTARY SCHOOLS

"Abernethy Elementary School." Programs. Portland Public Schools, 2013. Web. 01

Dec. 2013. <http://www.pps.k12.or.us/schools/abernethy/202.htm>.

Alvarez, L. (2004). Suutarila Journal; Educators Flocking to Finland, Land of Literate Children. New York Times.

Ardoin, Nicole, Charlotte Clark, and Elin Kelsey. "An Exploration of Future Trends in Environmental Research." Environmental Education Research (2013): 499-520.Portland State University. Web. 26 Nov. 2013. <http://dx.doi.org/10.1080/13504622.2012.709823>.

Barth, P. (2008, August 6). Time out: Is recess in danger? Retrieved October 3, 2014, from http://www.centerforpubliceducation.org/Main-Menu/Organizing-a-school/Time-out-Isrecess-in-danger

Barros, R. M., Silver, E. J., \& Stein, R. E. (2009). School recess and group classroom behavior. Pediatrics, 123(2), 431-436.

Buckingham, J., Wheldall, K., \& Beaman-Wheldall, R. (2013). Why poor children are more likely to become poor readers: The school years. Australian Journal of Education, 57(3), 190-213.

Bienenstock, Adam. "Making the Case for Natural Playgrounds." Interaction (Spring 2010): n. pag. Web. 26 Nov. 2013. <http://tachedaycare.com/Articles/Case.pdf>. Bilandzija, D. Education For the Next Generation of Eco- - System Thinkers. Flom, B., Johnson, C., Hubbard, J., \& Reidt, D. (January 01, 2011). The Natural School Counselor: Using Nature to Promote Mental Health in Schools. Journal of Creativity in Mental Health, 6, 2, 118-131.

Frumkin, Howard, DrPH. "The Evidence of Nature and the Nature of Evidence." American Journal of Preventative Medicine (2013): 196-97. JSTOR. Web. 26 Nov. 
OUTDOOR TIME IN PORTLAND ELEMENTARY SCHOOLS

2013. <http://socialcapitalreview.org/wp-

content/uploads/2013/01/frumkin_commentary_ajpm.pdf>.

"Gardenofwonders.org." Abernathy School Kitchen Garden. N.p., n.d. Web. 29 Nov.

2013. <http://gardenofwonders.org/>.

Hill, N. R. (October 01, 2007). Wilderness Therapy as a Treatment Modality for At-Risk

Youth: A Primer for Mental Health Counselors. Journal of Mental Health Counseling, 29,4.

Jarrett, O. (2013, November 1). A Research-Based Case for Recess. Retrieved August 19, 2014, from http://www.playworks.org/sites/default/files/US-play-coalition_Research-based-casefor-recess.pdf

Lindemann-Matthies, P., \& Knecht, S. (2011). Swiss Elementary School Teachers' Attitudes Toward Forest Education. The Journal of Environmental Education, 152-167.

Louv, R. (2008). Last child in the woods: Saving our children from nature-deficit disorder. Chapel Hill, NC: Algonquin Books of Chapel Hill.

Louv, R. (2011). The nature principle: Human restoration and the end of nature-deficit disorder. Chapel Hill, N.C.: Algonquin Books of Chapel Hill.

Mallonee, N., London, R., Stokes-Guinan, K., Westrich, L., \& McLaughlin, M. (2011, January 1). Playworks: Supporting Play and Physical Activity in Low-Income Elementary Schools. Retrieved September 1, 2014, from http://gardnercenter.stanford.edu/resources/reports/4632.63651.playandphysicalactivity.pdf

October 1, 2013 Enrollment - Summary Comparison. (2014, January 9). Retrieved January 19, 2014, from http://www.pps.k12.or.us/files/dataanalysis/2013_Enrollment_Summary.pdf 
OUTDOOR TIME IN PORTLAND ELEMENTARY SCHOOLS

Opportunities to Increase the Amount and Quality of Instructional Time - A report by the District Performance Auditor. (2007, September 1). Retrieved September 5, 2014, from http://www.pps.k12.or.us/files/board/instructional_time_audit_07.pdf

Orr, D. (1991). What is education for. Context, 27, 52-55.

Parr, H. (January 01, 2007). Mental health, nature work, and social inclusion.

Environment and Planning. D, Society \& Space, 25, 3, 537-561.

Physical Activity Other Than Physical Education. (2013, September 18). Retrieved

December 8, 2014, from http://www.nasbe.org/healthy_schools/hs/bytopics.php?topicid=3120

Portland Public Schools - About Portland Public Schools. (2014). Retrieved from http://www.pps.k12.or.us/about-us/index.htm\

"Portland Public Schools." Portland Public Schools. N.p., 2013. Web. 28 Nov. 2013. $<$ http://www.pps.k12.or.us/>.

Pulse: New recess program keeps the peace. (2010, February 19). Retrieved August 5, 2014, from http://www.pps.k12.or.us/news/2774.htm

Randall, Robin, AIA, LEED BC\&C. "Inspired to Learn; Nurturing the Naturalistic Learner."The 9th Ball State University Greening of the Campus Conference (2012): n. pag. Web. 26 Nov. 2013.

Roth, J., Linver, M., Hofferth, S., \& Brooks-Gunn, J. (2003). What happens during the school day?: Time diaries from a national sample of elementary school teachers. The Teachers College Record, 105(3), 317-343.

Sallis, J. F., McKenzie, T. L., Kolody, B., Lewis, M., Marshall, S., \& Rosengard, P. (1999). Effects of health-related physical education on academic achievement: Project SPARK. Research quarterly for exercise and sport, 70(2), 127-134. 
OUTDOOR TIME IN PORTLAND ELEMENTARY SCHOOLS

Sirin, S. R. (2005). Socioeconomic status and academic achievement: A meta-analytic review of research. Review of educational research, 75(3), 417-453.

Sobel, D. (2014, Spring). The Best Way to Learn About a Tree. Retrieved June 10, 2014, from http://www.antiochne.edu/wp-content/uploads/2014/03/Yes-Forest-K.pdf

Stewart, I. T., Purner, E. K., \& Guzmán, P. D. (2013). Socioeconomic Disparities in the Provision of School Gardens in Santa Clara County, California. Children Youth and Environments, 23(2), 127-153.

"Students Get a Taste of Nature through Outdoor School." Portland Public Schools. N.p., 4 Nov. 2009. Web. 01 Dec. 2013. <http://www.pps.k12.or.us/news/1710.htm>.

Stull, J. C. (2013). Family socioeconomic status, parent expectations, and a child's achievement. Research in Education, 90(1), 53-67.

Swarbrick, N., Eastwood, G., \& Tutton, K. (2004). Self-esteem and successful interaction as part of the forest school project. Support for Learning, 142-146.

Tracy, D. (2007). Opportunities to Increase the Amount and Quality of Instructional Time - A report by the District Performance Auditor September 2007. Retrieved November 10, 2014, from http://www.pps.k12.or.us/files/board/instructional_time_audit_07.pdf

Wilson, Ruth. "Becoming Whole: Developing an Ecological Identity." NACC Newsletter(May-June 2011): n. pag. Web. 26 Nov. 2013. <http://cciemedia.s3.amazonaws.com/nacc/wonder_may11.pdf>.

Wells, N. M., \& Evans, G. W. (2003). Nearby nature a buffer of life stress among rural children. Environment and Behavior, 35(3), 311-330.

Yancey, A. K. (2010). Instant Recess: Building a fit nation 10 minutes at a time. Univ of California Press. 
OUTDOOR TIME IN PORTLAND ELEMENTARY SCHOOLS

Yeşil Dağl1, Ü. (2012). Recess and Reading Achievement of Early Childhood Students in Public Schools. Education Policy Analysis Archives, 20, 10.

doi:http://dx.doi.org/10.14507/epaa.v20n10.2012

\section{Appendix A}

Table 1 displays the data regarding outdoor time and percentage of students receiving free and reduced price lunch for the fifty-eight Portland public elementary schools included in this study.

Table 1. Outdoor Time and Socioeconomic Status Data for Portland Public Elementary Schools

\begin{tabular}{|l|l|l|l|l|l|l|}
\hline Scho & Length & Recess Time & Additional Outdoor & Outdoor & $\%$ \\
\hline
\end{tabular}


OUTDOOR TIME IN PORTLAND ELEMENTARY SCHOOLS

\begin{tabular}{|c|c|c|c|c|c|c|c|}
\hline \multirow[t]{2}{*}{ ol \# } & \multirow[b]{2}{*}{$\begin{array}{l}\text { Name of } \\
\text { School }\end{array}$} & \multirow{2}{*}{$\begin{array}{c}\text { of } \\
\text { School } \\
\text { Day }\end{array}$} & & \multicolumn{2}{|c|}{ Opportunities } & \multirow{2}{*}{$\begin{array}{c}\text { time } \\
\text { (Recess) } \\
\text { as \% of } \\
\text { school } \\
\text { day }\end{array}$} & \multirow{2}{*}{$\begin{array}{l}\text { students } \\
\text { who } \\
\text { receive } \\
\text { free/ } \\
\text { reduced } \\
\text { price } \\
\text { lunch, } \\
2013\end{array}$} \\
\hline & & & & PE Time & $\begin{array}{l}\text { School } \\
\text { Garden }\end{array}$ & & \\
\hline 1 & $\begin{array}{l}\text { Forest Park (K- } \\
5)\end{array}$ & & $20 \mathrm{~min}$ & $\begin{array}{l}\text { 2x per week } \\
\text { for } 30 \mathrm{~min}\end{array}$ & yes & & 2 \\
\hline 2 & $\begin{array}{c}\text { Ainsworth } \square(\mathrm{K} \\
-5)\end{array}$ & $\begin{array}{l}\square 6 \mathrm{hr} \\
25 \mathrm{~min}\end{array}$ & $25 \mathrm{~min}$ & $\begin{array}{l}1-2 x / \text { week } \\
\text { for 30min }\end{array}$ & Yes & 6.5 & 4.9 \\
\hline 3 & $\begin{array}{c}\text { Alameda (PK- } \\
5)\end{array}$ & & 20 min outside & $2 \mathrm{x}$ per week & Yes & & 7.1 \\
\hline 4 & $\begin{array}{l}\text { Stephenson (K- } \\
5)\end{array}$ & $\begin{array}{c}6 \mathrm{hr} \\
22 \mathrm{~min}\end{array}$ & $\begin{array}{l}\text { 30min lunch } \\
\text { recess and } \\
15 \mathrm{~min} \text { extra } \\
\text { recess }\end{array}$ & $\begin{array}{l}\text { 30min, } \\
1 \mathrm{x} / \text { week }\end{array}$ & no & 11.8 & 9.1 \\
\hline 5 & $\begin{array}{c}\text { Richmond } \square(\mathrm{P} \\
\mathrm{K}-5)\end{array}$ & $\begin{array}{c}\square 6 \mathrm{hr} \\
15 \mathrm{~min}\end{array}$ & $\begin{array}{l}20 \mathrm{~min} \text { and } \\
\text { other } \\
\text { recess/breaks } \\
\text { are up to the } \\
\text { teacher }\end{array}$ & $\begin{array}{l}1 \mathrm{x} / \text { week and } \\
\text { length varies }\end{array}$ & yes & 5.3 & 10.2 \\
\hline 6 & $\begin{array}{c}\text { Beverly } \\
\text { Cleary } \square @ \square \mathrm{Fe} \\
\text { rnwood Campu } \\
\text { s (2-8) }\end{array}$ & $\begin{array}{c}6 \mathrm{hr} \\
25 \mathrm{~min}\end{array}$ & $\begin{array}{c}2-3 \mathrm{rd} \text { is } \\
15 \mathrm{mins} \\
4-5 \mathrm{th} \text { is } 20 \mathrm{~min}\end{array}$ & $\begin{array}{c}55 \mathrm{~min}, 1 \\
\text { time/week }\end{array}$ & yes & 5.2 & 10.6 \\
\hline 7 & $\begin{array}{c}\text { Beverly } \\
\text { Cleary } \square @ \text { Ho } \\
\text { llywood } \\
\text { Campus (K-1) }\end{array}$ & $\begin{array}{c}6 \mathrm{hr} \\
25 \mathrm{~min}\end{array}$ & $\begin{array}{l}\text { K-1 } 25 \text { min but } \\
\text { they go } \\
\text { outside more } \\
\text { times during } \\
\text { the day } \\
\text { according } \\
\text { to the } \\
\text { teacher's discr } \\
\text { etion }\end{array}$ & none & yes & $6.5 \%$ & 10.6 \\
\hline 8 & Duniway (K-5) & $\begin{array}{c}6 \mathrm{hr} \\
15 \mathrm{~min}\end{array}$ & $\begin{array}{l}20-25 \mathrm{~min} \text { as } \\
\text { well as a } \\
15 \mathrm{~min} \\
\text { morning and } \\
\text { afternoon } \\
\text { recess }\end{array}$ & $\begin{array}{l}2 x \text { per week } \\
\text { for } 40 \mathrm{~min}\end{array}$ & yes & $14 \%$ & 11.2 \\
\hline 9 & $\begin{array}{c}\text { Winterhaven } \square( \\
\text { K-8) }\end{array}$ & $\begin{array}{c}\square 6 \mathrm{hr} \\
15 \mathrm{~min}\end{array}$ & $\begin{array}{l}25-30 \mathrm{~min} \text {, and } \\
8-10 \mathrm{~min} \\
\text { morning and } \\
\text { afternoon } \\
\text { recess too }\end{array}$ & $\begin{array}{c}2 \mathrm{x} / \text { week for } \\
60 \mathrm{~min}\end{array}$ & & $12.1 \%$ & 11.8 \\
\hline 10 & $\begin{array}{c}\text { ACCESS } \\
\text { Alternative } \\
\text { Program (1-8) }\end{array}$ & $\begin{array}{c}\square 6 \mathrm{hr} \\
15 \mathrm{~min}\end{array}$ & 40 & $\square$ & Yes & & 12.3 \\
\hline
\end{tabular}


OUTDOOR TIME IN PORTLAND ELEMENTARY SCHOOLS

\begin{tabular}{|c|c|c|c|c|c|c|c|}
\hline 11 & $\begin{array}{c}\text { Laurelhurst (K- } \\
8)\end{array}$ & $\begin{array}{l}\square 6 \mathrm{hr} \\
25 \mathrm{~min}\end{array}$ & $\square 20 \mathrm{~min}$ & $\begin{array}{l}30 \mathrm{~min}, \\
2 \mathrm{x} / \mathrm{week}\end{array}$ & yes & $5.2 \%$ & 13.4 \\
\hline 12 & $\begin{array}{l}\text { Bridlemile (K- } \\
5)\end{array}$ & $\begin{array}{c}6 \mathrm{hr} \\
15 \mathrm{~min}\end{array}$ & $\begin{array}{l}20 \mathrm{~min} \text { and } \\
\text { may get more } \\
\text { breaks } \\
\text { depending on } \\
\text { teacher and } \\
\text { classroom }\end{array}$ & $\begin{array}{l}2 \mathrm{x} \text { per week } \\
\text { for } 35 \mathrm{~min}\end{array}$ & $\begin{array}{c}\text { Yes but } \\
\text { no } \\
\text { veggies, } \\
\text { just } \\
\text { plants }\end{array}$ & $5.3 \%$ & 16 \\
\hline 13 & Hayhurst (K-5) & $\begin{array}{c}\square 6 \mathrm{hr} \\
20 \mathrm{~min}\end{array}$ & $\begin{array}{l}\square 25 \mathrm{~min} \text { and } \\
\text { any extra } \\
\text { recess is up to } \\
\text { the teacher }\end{array}$ & $\begin{array}{l}30 \mathrm{~min}, 2 \mathrm{x} \\
\text { per week }\end{array}$ & no & $6.6 \%$ & 16.4 \\
\hline 14 & Rieke (K-5) & $\begin{array}{c}\square 6 \mathrm{hr} \\
15 \mathrm{~min}\end{array}$ & $23 \mathrm{~min}$ & $\begin{array}{c}\text { 30min PE } \\
\text { and 30min } \\
\text { dance } \\
1 \mathrm{x} / \text { week }\end{array}$ & $\begin{array}{c}\text { Yes, } \\
\text { native } \\
\text { plant } \\
\text { garden, } \\
\text { part of } \\
\text { curricul } \\
\text { um }\end{array}$ & $6.1 \%$ & 17.3 \\
\hline 15 & $\begin{array}{l}\text { Llewellyn (K- } \\
5)\end{array}$ & $\begin{array}{c}\square 6 \mathrm{hr} \\
15 \mathrm{~min}\end{array}$ & $\begin{array}{l}25 \mathrm{~min} \text { and any } \\
\text { other } \\
\text { recess/breaks } \\
\text { are up to the } \\
\text { teacher }\end{array}$ & $\begin{array}{l}\text { 30min, } \\
\text { 2x/week }\end{array}$ & yes & $6.7 \%$ & 23 \\
\hline 16 & Glencoe (K-5) & $\begin{array}{c}6 \mathrm{hr} \\
20 \mathrm{~min}\end{array}$ & $\begin{array}{l}25 \mathrm{~min} \text { and the } \\
\text { younger } \\
\text { students get an } \\
\text { extra } 20 \mathrm{~min} \\
\text { morning } \\
\text { recess too }\end{array}$ & $\begin{array}{l}\text { 1x per week } \\
\text { for } 35 \mathrm{~min}\end{array}$ & no & $9.2 \%$ & 25.3 \\
\hline 17 & $\begin{array}{l}\text { Maplewood } \\
(\mathrm{K}-5)\end{array}$ & $\begin{array}{c}6 \mathrm{hr} \\
15 \mathrm{~min} \\
\square\end{array}$ & $\begin{array}{c}\square 10-15 \mathrm{~min} \\
\text { and } \mathrm{K}-2^{\text {nd }} \text { also } \\
\text { have } 10 \mathrm{~min} \\
\text { morning } \\
\text { recess }\end{array}$ & $\begin{array}{l}\text { 30min, } \\
\text { 2x/week }\end{array}$ & Yes & $4.7 \%$ & 25.8 \\
\hline 18 & $\begin{array}{l}\text { Capitol Hill } \\
(\mathrm{K}-5)\end{array}$ & $\begin{array}{c}6 \mathrm{hr} \\
25 \mathrm{~min}\end{array}$ & 20-25mins & 1hr/week & $\begin{array}{l}\text { Yes but } \\
\text { use } \\
\text { changes } \\
\text { year to } \\
\text { year }\end{array}$ & $5.8 \%$ & 26.9 \\
\hline 19 & $\begin{array}{c}\text { Sunnyside } \\
\text { Environmental } \\
(\mathrm{K}-8)\end{array}$ & $\begin{array}{l}\square 6 \mathrm{hr} \\
20 \mathrm{~min}\end{array}$ & $\begin{array}{l}\text { K-2nd } 30 \mathrm{~min} \\
\text { lunch recess } \\
\text { and } 15 \mathrm{~min} \\
\text { morning and } \\
15 \mathrm{~min} \\
\text { afternoon } \\
\text { recess, } \\
\text { 3rd-5th have } \\
\text { 30min lunch } \\
\text { recess and }\end{array}$ & $\begin{array}{c}1 \mathrm{st}-2 \mathrm{nd} \\
30 \mathrm{~min} \\
2 \mathrm{x} / \text { week, } \\
3^{\text {rd }} 50 \mathrm{~min} \\
1 \mathrm{x} / \text { week, } \\
4^{\text {th }} 60 \mathrm{~min} \\
1 \mathrm{x} / \text { week, } \\
5^{\text {th }} 45 \mathrm{~min} \\
1 \mathrm{x} / \text { week }\end{array}$ & $\begin{array}{l}\text { Yes, and } \\
\text { it is part } \\
\text { of } \\
\text { curricul } \\
\text { um }\end{array}$ & $13.8 \%$ & 27.6 \\
\hline
\end{tabular}


OUTDOOR TIME IN PORTLAND ELEMENTARY SCHOOLS

\begin{tabular}{|c|c|c|c|c|c|c|c|}
\hline & & & $\begin{array}{c}15 \mathrm{~min} \\
\text { morning } \\
\text { recess }\end{array}$ & & & & \\
\hline 20 & Chapman (K-5) & $\begin{array}{c}6 \mathrm{hr} \\
20 \mathrm{~min}\end{array}$ & $\begin{array}{c}20 \mathrm{~min} \\
\text { minimum but } \\
\text { may be longer } \\
\text { and extra } \\
\text { recesses are } \\
\text { up to the } \\
\text { teacher's } \\
\text { discretion, K- } \\
1 \text { st have } \\
\text { a morning and } \\
\text { afternoon } \\
15 \text { min recess } \\
\text { too }\end{array}$ & $\begin{array}{l}2 \mathrm{x} \text { per week } \\
\text { for } 20 \mathrm{~min}\end{array}$ & $\begin{array}{l}\text { Yes and } \\
\text { the } \\
\text { teachers } \\
\text { have the } \\
\text { option } \\
\text { to have } \\
\text { a plot in } \\
\text { the } \\
\text { garden }\end{array}$ & $7.2 \%$ & 29.1 \\
\hline 21 & Skyline (K-8) & $\begin{array}{c}\square 6 \mathrm{hr} \\
15 \mathrm{~min}\end{array}$ & $22 \min$ & $\begin{array}{l}\square 30 \mathrm{~min}, \\
2 \mathrm{x} / \text { week }\end{array}$ & $\begin{array}{l}\text { Yes, but } \\
\text { not used } \\
\text { during } \\
\text { class }\end{array}$ & $5.9 \%$ & 29.8 \\
\hline 22 & $\begin{array}{l}\text { Woodstock } \square( \\
\text { K-5) }\end{array}$ & $\begin{array}{c}\square 6 \mathrm{hr} \\
20 \mathrm{~min}\end{array}$ & $\begin{array}{l}25 \mathrm{~min} \text { and any } \\
\text { other recess is } \\
\text { up to the } \\
\text { teacher's } \\
\text { discretion }\end{array}$ & $\begin{array}{c}\square 30 \mathrm{~min}(\mathrm{~K}- \\
2,1 \mathrm{x} / \text { week }) \\
\quad(3- \\
5,2 \mathrm{x} / \text { week })\end{array}$ & $\begin{array}{l}\text { Yes but } \\
\text { no water } \\
\text { source } \\
\text { so it is } \\
\text { not used }\end{array}$ & $6.6 \%$ & 31.3 \\
\hline 23 & Sabin (PK-8) & $\begin{array}{l}\square 6 \mathrm{hr} \\
30 \mathrm{~min}\end{array}$ & $\begin{array}{l}40 \mathrm{~min} \text { lunch } \\
\& \text { recess and } \\
\text { other recesses } \\
\text { are up to the } \\
\text { teacher }\end{array}$ & $\begin{array}{l}\text { Varies by } \\
\text { grade } \\
\sim 1 \mathrm{x} / \text { week } \\
(\mathrm{K}-30 \mathrm{~min}) \\
\left(5^{\text {th }}-45 \mathrm{~min}\right)\end{array}$ & $\begin{array}{l}\text { Yes, use } \\
\text { it during } \\
\text { class } \\
\text { and } \\
\text { during } \\
\text { SUN } \\
\text { program }\end{array}$ & $5.1 \%$ & 32 \\
\hline 24 & Irvington (K-8) & $\begin{array}{c}\square 6 \mathrm{hr} \\
20 \mathrm{~min}\end{array}$ & $\begin{array}{l}\text { 20min and any } \\
\text { extra recess is } \\
\text { up to the } \\
\text { teacher }\end{array}$ & $\begin{array}{c}50 \mathrm{~min} \text { and } \\
\text { the \# of times } \\
\text { per week } \\
\text { varies }\end{array}$ & yes & $5.3 \%$ & 33.1 \\
\hline 25 & $\begin{array}{c}\text { Buckman Arts } \\
\square(\mathrm{K}-5)\end{array}$ & $\begin{array}{c}6 \mathrm{hr} \\
25 \mathrm{~min}\end{array}$ & $25-30 \mathrm{~min}$ & $\begin{array}{l}\text { about } 1 \text { time } \\
\text { per week but } \\
\text { there is no } \\
\text { PE teacher so } \\
\text { it depends on } \\
\text { the instructor } \\
\text { of the class, } \\
\text { the teacher } \\
\text { takes the } \\
\text { children out } \\
\text { for PE }\end{array}$ & $\begin{array}{l}\text { Yes but } \\
\text { only the } \\
\text { aftersch } \\
\text { ool } \\
\text { SUN pr } \\
\text { ogram } \\
\text { uses it, } \\
\text { not the } \\
\text { students }\end{array}$ & $7.1 \%$ & 34.7 \\
\hline 26 & $\begin{array}{c}\text { Creative } \\
\text { Science } \\
\text { School } \square(\mathrm{K}-8)\end{array}$ & $\begin{array}{c}6 \mathrm{hr} \\
20 \mathrm{~min}\end{array}$ & $20 \mathrm{~min}$ & $\begin{array}{l}\text { 1x per week } \\
\text { for } 30 \mathrm{~min}\end{array}$ & & $5.3 \%$ & 34.8 \\
\hline
\end{tabular}


OUTDOOR TIME IN PORTLAND ELEMENTARY SCHOOLS

\begin{tabular}{|c|c|c|c|c|c|c|c|}
\hline 27 & Lewis $(\mathrm{K}-5)$ & $\begin{array}{c}\square 6 \mathrm{hr} \\
20 \mathrm{~min}\end{array}$ & $\begin{array}{l}\text { 30min recess } \\
\text { and 'brain } \\
\text { breaks' } \\
\text { throughout the } \\
\text { day }\end{array}$ & $\begin{array}{l}\text { 35min, } \\
\text { 2x/week }\end{array}$ & $\begin{array}{l}\text { Yes and } \\
\text { it is part } \\
\text { of } \\
\text { curricul } \\
\text { um }\end{array}$ & $7.9 \%$ & 37 \\
\hline 28 & $\begin{array}{c}\text { Atkinson } \square(\mathrm{K}- \\
5)\end{array}$ & $\begin{array}{c}6 \mathrm{hr} \\
25 \mathrm{~min}\end{array}$ & $\begin{array}{l}\text { 20min recess } \\
\text { mid-day. K- } \\
\text { 3rd have } \\
10 \text { min } \\
\text { morning } \\
\text { recess and K- } \\
5 \text { th have } \\
\text { afternoon } 10 \\
\text { min recess }\end{array}$ & $\begin{array}{l}2 x \text { per week } \\
\text { for } 30 \mathrm{~min}\end{array}$ & yes & $7.8 \%$ & 41.5 \\
\hline 29 & $\begin{array}{c}\text { Roseway Heigh } \\
\text { ts }(\mathrm{K}-8)\end{array}$ & $\square$ & $\begin{array}{c}\text { 20min and } \\
\text { other recesses } \\
\text { are up to the } \\
\text { teacher }\end{array}$ & $\begin{array}{l}2 \mathrm{x} / \text { week for } \\
45 \mathrm{~min}\end{array}$ & Yes & & 42.2 \\
\hline 30 & Markham (K-5) & $\begin{array}{c}\square 6 \mathrm{hr} \\
20 \mathrm{~min}\end{array}$ & $\begin{array}{l}\text { 20min and any } \\
\text { other } \\
\text { recess/breaks } \\
\text { are up to the } \\
\text { teacher }\end{array}$ & $\begin{array}{l}\square 30 \mathrm{~min}, \\
2 \mathrm{x} / \text { week }\end{array}$ & $\begin{array}{l}\text { Yes, but } \\
\text { not part } \\
\text { of the } \\
\text { curricul } \\
\text { um }\end{array}$ & $5.3 \%$ & 52.7 \\
\hline 31 & $\begin{array}{c}\text { CJOG } \\
@ \square \text { Chief } \\
\text { Joseph } \square \text { Camp } \\
\text { us (K-3) }\end{array}$ & $\begin{array}{c}6 \mathrm{hr} \\
15 \mathrm{~min}\end{array}$ & $\begin{array}{l}\mathrm{K}-3 \mathrm{rd} \text { have } \\
\text { 30min and any } \\
\text { more time } \\
\text { outside is up } \\
\text { to the teacher }\end{array}$ & $\begin{array}{l}\text { 30min every } \\
\text { other day }\end{array}$ & yes & $8 \%$ & 53.4 \\
\hline 32 & $\begin{array}{c}\text { CJOG } \\
\text { @ Ockley Gree } \\
\text { n Campus (4-8) }\end{array}$ & $\begin{array}{c}6 \mathrm{hr} \\
15 \mathrm{~min}\end{array}$ & 20min & $\begin{array}{c}\text { 2x per week } \\
\text { for } 45 \text { min } \\
\text { but } \\
\text { sometimes } \\
\text { they have } \\
\text { dance rather } \\
\text { than outdoor } \\
\text { PE }\end{array}$ & $\begin{array}{l}\text { Yes, the } \\
\text { SUN } \\
\text { program } \\
\text { uses it. }\end{array}$ & $5.3 \%$ & 53.4 \\
\hline 33 & Astor (K-8) & $\begin{array}{c}6 \mathrm{hr} \\
25 \mathrm{~min}\end{array}$ & $\begin{array}{l}\text { K-3rd have } \\
20 \text { min recess } \\
\text { after lunch } \\
\text { and } 15 \mathrm{~min} \\
\text { morning } \\
\text { recess. } 4 \text { th-5th } \\
\text { have } 20 \text { min } \\
\text { recess after } \\
\text { lunch }\end{array}$ & $\begin{array}{l}\text { K-3rd 2x per } \\
\text { week for } \\
\text { 30min. 4th- } \\
\text { 5th have it } 2 \mathrm{x} \\
\text { per week for } \\
45 \text { min }\end{array}$ & $\begin{array}{c}\text { No, only } \\
\text { a } \\
\text { decorati } \\
\text { ve } \\
\text { garden } \\
\text { of } \\
\text { native } \\
\text { plants }\end{array}$ & $7.1 \%$ & 53.6 \\
\hline 34 & Vernon (K-8) & $\begin{array}{l}\square 6 \mathrm{hr} \\
20 \mathrm{~min}\end{array}$ & $\begin{array}{l}15 \text { min and any } \\
\text { other recess is } \\
\text { up to the } \\
\text { teacher's } \\
\text { discretion }\end{array}$ & $\begin{array}{l}\text { 1x/week for } \\
\text { 40min and } \\
\text { teacher can } \\
\text { use gym } 1 \\
\text { more }\end{array}$ & $\begin{array}{l}\text { Yes, and } \\
\text { it is part } \\
\text { of } \\
\text { curricul } \\
\text { um }\end{array}$ & $3.9 \%$ & 54.6 \\
\hline
\end{tabular}


OUTDOOR TIME IN PORTLAND ELEMENTARY SCHOOLS

\begin{tabular}{|c|c|c|c|c|c|c|c|}
\hline & & & & $\begin{array}{c}\text { time/week if } \\
\text { desired }\end{array}$ & & & \\
\hline 35 & Beach $\square(\mathrm{K}-8)$ & $\begin{array}{c}6 \mathrm{hr} \\
15 \mathrm{~min}\end{array}$ & $\square$ & $\square$ & & & 58.1 \\
\hline 36 & Creston (K-8) & $\begin{array}{c}6 \mathrm{hr} \\
15 \mathrm{~min}\end{array}$ & $20 \mathrm{~min}$ & $\begin{array}{l}2 \mathrm{x} \text { per week } \\
\text { for } 30 \mathrm{~min}\end{array}$ & $\begin{array}{l}\text { No, but } \\
\text { one is } \\
\text { being } \\
\text { built as } \\
\text { part of } \\
\text { de- } \\
\text { paving } \\
\text { project }\end{array}$ & $5.3 \%$ & 63.7 \\
\hline 37 & Bridger $\square(\mathrm{K}-8)$ & $\begin{array}{c}6 \mathrm{hr} \\
20 \mathrm{~min}\end{array}$ & $\begin{array}{l}15 \mathrm{~min} \text { as well } \\
\text { as } 5 \text { minute } \\
\text { breaks } \\
\text { throughout the } \\
\text { day }\end{array}$ & $\begin{array}{l}2 \times \text { per week } \\
\text { for } 30-45 \mathrm{~min}\end{array}$ & yes & $5.3 \%$ & 63.9 \\
\hline 38 & Grout (K-5) & $\begin{array}{l}\square 6 \mathrm{hr} \\
25 \mathrm{~min}\end{array}$ & About $17 \mathrm{~min}$ & $\begin{array}{l}\text { 1x per week } \\
\text { for } 45 \mathrm{~min}\end{array}$ & yes & $4.4 \%$ & 64.7 \\
\hline 39 & Arleta (K-8) & $\begin{array}{l}\square 6 \mathrm{hr} \\
20 \mathrm{~min}\end{array}$ & $\square$ & $\square$ & yes & & 65.8 \\
\hline 40 & $\begin{array}{c}\text { Peninsula } \square(\mathrm{K}- \\
8)\end{array}$ & $\begin{array}{c}\square 6 \mathrm{hr} \\
15 \mathrm{~min}\end{array}$ & $\begin{array}{c}25 \mathrm{~min} \text { (no } \\
\text { other recess!) }\end{array}$ & $\begin{array}{l}\square \text { Full time } \\
\text { PE teacher } \\
\text { but no data }\end{array}$ & $\begin{array}{l}\text { Yes, and } \\
\text { part of } \\
\text { curricul } \\
\text { um }\end{array}$ & $6.7 \%$ & 69.9 \\
\hline 41 & Vestal (K-8) & $\begin{array}{l}\square 6 \mathrm{hr} \\
15 \mathrm{~min}\end{array}$ & $15 \mathrm{~min}$ & $\square$ None & Yes & $4 \%$ & 73.9 \\
\hline 42 & Lee $(\mathrm{K}-8)$ & & $\begin{array}{c}\text { 20min midday } \\
\text { recess and } \\
15 \mathrm{~min} \\
2^{\text {nd }} \text { recess }\end{array}$ & $\begin{array}{l}1 \text { hour } 2-3 x \\
\text { per week }\end{array}$ & Yes & & 75.9 \\
\hline 43 & Faubion (PK-8) & $\begin{array}{c}6 \mathrm{hr} \\
15 \mathrm{~min}\end{array}$ & $20 \mathrm{~min}$ & & $9 / 26$ & $5.3 \%$ & 77.4 \\
\hline 44 & $\begin{array}{l}\text { James John (K- } \\
5)\end{array}$ & $\begin{array}{c}6 \mathrm{hr} \\
15 \mathrm{~min}\end{array}$ & $25 \mathrm{~min}$ & $\begin{array}{l}\text { 30min, } 2 \mathrm{x} \\
\text { per week }\end{array}$ & no & $6.7 \%$ & 79.6 \\
\hline 45 & $\begin{array}{c}\text { Marysville } \square(\mathrm{K} \\
-8)\end{array}$ & $\begin{array}{l}\square 6 \mathrm{hr} \\
20 \mathrm{~min}\end{array}$ & $\sim 20 \mathrm{~min}$ recess & $\begin{array}{c}\text { 40min } \\
\text { 1x/week PE, } \\
\text { and Playwork } \\
\text { s outdoors } \\
1 \mathrm{x} / \text { week } \square\end{array}$ & no & $5.3 \%$ & 80.3 \\
\hline 46 & Kelly $\square(\mathrm{K}-5)$ & $\begin{array}{l}\square 6 \mathrm{hr} \\
25 \mathrm{~min}\end{array}$ & $\square 20 \mathrm{~min}$ & $\begin{array}{l}\square 1 \mathrm{x} / \text { week } \\
\text { for 45min }\end{array}$ & yes & $5.2 \%$ & 80.9 \\
\hline 47 & $\begin{array}{c}\text { Boise- } \\
\text { Eliot/Humboldt } \\
\text { (PK-8) }\end{array}$ & $\begin{array}{c}6 \mathrm{hr} \\
20 \mathrm{~min}\end{array}$ & $30 \mathrm{~min}$ recess & $\begin{array}{c}\text { 30min, } 1 \mathrm{x} \\
\text { per week }\end{array}$ & yes & $7.9 \%$ & 83.4 \\
\hline 48 & Lent $\square$ (K-8) & $\begin{array}{c}\square 6 \mathrm{hr} \\
20 \mathrm{~min}\end{array}$ & $\begin{array}{l}\text { 20min, and } \\
\text { usually have } \\
\text { anothre } 15- \\
\text { 20min recess } \\
\text { (sometimes a }\end{array}$ & $\begin{array}{c}1 \mathrm{x} / \text { week } 40- \\
45 \mathrm{~min}\end{array}$ & $\begin{array}{l}\text { Yes, but } \\
\text { not part } \\
\text { of } \\
\text { curricul } \\
\text { um }\end{array}$ & $9.2 \%$ & 83.6 \\
\hline
\end{tabular}


OUTDOOR TIME IN PORTLAND ELEMENTARY SCHOOLS

\begin{tabular}{|c|c|c|c|c|c|c|c|}
\hline & & & third recess) & & & & \\
\hline 49 & Scott $(K-8)$ & $\begin{array}{l}\square 6 \mathrm{hr} \\
20 \mathrm{~min}\end{array}$ & $\begin{array}{l}\square \text { 20min reces } \\
\text { s \& lunch }\end{array}$ & $\begin{array}{c}55 \mathrm{~min} \\
1 \mathrm{x} / \text { week }\end{array}$ & yes & $2.6 \%$ & 84.2 \\
\hline 50 & $\begin{array}{l}\text { Woodlawn } \\
\text { (PK-8) }\end{array}$ & $\square$ & $20 \mathrm{~min}$ & $\begin{array}{l}\text { 30-35min, } \\
1 \mathrm{x} / \text { week }\end{array}$ & $\begin{array}{c}\text { Yes, but } \\
\text { not used } \\
\text { by } \\
\text { students }\end{array}$ & & 84.2 \\
\hline 51 & $\begin{array}{c}\text { Woodmere (K- } \\
5)\end{array}$ & $\begin{array}{l}\square 6 \mathrm{hr} \\
30 \mathrm{~min}\end{array}$ & $\begin{array}{l}\text { 25-28min } \\
\text { and Playworks } \\
1 \mathrm{x} / \text { week if } \\
\text { sunny }\end{array}$ & $\begin{array}{l}\text { 1x/week for } \\
30 \mathrm{~min}\end{array}$ & $\begin{array}{l}\text { Yes but } \\
\text { part of } \\
\text { SUN } \\
\text { summer } \\
\text { school }\end{array}$ & $6.8 \%$ & 84.9 \\
\hline 52 & $\begin{array}{c}\text { Harrison } \\
\text { Park } \square(\mathrm{K}-8)\end{array}$ & $\begin{array}{c}\square 6 \mathrm{hr} \\
15 \mathrm{~min}\end{array}$ & $\begin{array}{l}\text { About 20min } \\
\text { (but not all } \\
\text { teachers take } \\
\text { students } \\
\text { outside) } \\
\mathrm{K}-2^{\text {nd }} \text { go } \\
\text { outside for } \\
\text { another recess } \\
\text { if it is sunny }\end{array}$ & $\begin{array}{l}\square 30 \text { min per } \\
\text { week but } \\
\text { quarterly } \\
\text { rotation so } \\
\text { some } \\
\text { quarters they } \\
\text { don't have } \\
\text { PE }\end{array}$ & $\begin{array}{l}\text { Yes, } \\
\text { sometim } \\
\text { es they } \\
\text { go out } \\
\text { to the } \\
\text { commun } \\
\text { ity } \\
\text { garden }\end{array}$ & $5.3 \%$ & 85.4 \\
\hline 53 & Sitton (K-5) & $\begin{array}{c}\square 6 \mathrm{hr} \\
15 \mathrm{~min}\end{array}$ & $\begin{array}{l}20 \mathrm{~min}(\mathrm{~K} \\
\text { have extra } \\
\text { recess but for } \\
\text { the other } \\
\text { grades any } \\
\text { additional } \\
\text { recess is up to } \\
\text { the teacher) }\end{array}$ & $\begin{array}{c}1 \mathrm{x} / \text { week for } \\
30 \mathrm{~min}\end{array}$ & Yes & $5.3 \%$ & 85.4 \\
\hline 54 & Rigler $\square(\mathrm{K}-8)$ & $\begin{array}{l}\square 6 \mathrm{hr} \\
15 \mathrm{~min}\end{array}$ & $\square 12-20 \mathrm{~min}$ & $\square$ & Yes & $4.3 \%$ & 86.2 \\
\hline 55 & Whitman (K-5) & $\begin{array}{c}\square 6 \mathrm{hr} \\
10 \mathrm{~min}\end{array}$ & $\begin{array}{l}\text { 20min, } \mathrm{K} \text { has } \\
\text { morning } \\
\text { recess too }\end{array}$ & $\begin{array}{c}40 \mathrm{~min} \\
\text { 2x/week }\end{array}$ & $\begin{array}{c}\text { Built } \\
\text { summer } \\
2014, \\
\text { not yet } \\
\text { part of } \\
\text { curricul } \\
\text { um }\end{array}$ & $5.4 \%$ & 86.2 \\
\hline 56 & $\begin{array}{c}\text { Cesar } \\
\text { Chavez } \square(\mathrm{K}-8)\end{array}$ & & & $45 \mathrm{~min}$ & $\begin{array}{c}\text { Yes, } \\
\text { also just } \\
\text { received } \\
\text { a } \\
\text { Growin } \\
\text { gGarden } \\
\text { Grant } \\
\text { to } \\
\text { improve } \\
\text { garden } \\
\text { for next } \\
\text { 3yrs }\end{array}$ & & 88.8 \\
\hline
\end{tabular}


OUTDOOR TIME IN PORTLAND ELEMENTARY SCHOOLS

\begin{tabular}{|c|c|c|c|c|c|c|c|}
\hline & & & & & $\begin{array}{l}\text { starting } \\
\text { Fall14) }\end{array}$ & & \\
\hline 57 & King (PK-8) & $\begin{array}{l}\square 6 \mathrm{hr} \\
20 \mathrm{~min}\end{array}$ & $\begin{array}{l}\text { 20min and } \\
\text { younger } \\
\text { grades have } \\
\text { 10min afterno } \\
\text { on recess }\end{array}$ & $30 \mathrm{~min}$ & $\begin{array}{l}\text { Yes, but } \\
\text { PTA is } \\
\text { in } \\
\text { charge } \\
\text { and no } \\
\text { info } \\
\text { regardin } \\
\text { g } \\
\text { students } \\
\text { use of } \\
\text { garden }\end{array}$ & $6.6 \%$ & 88.8 \\
\hline 58 & $\begin{array}{c}\text { Rosa Parks (K- } \\
5)\end{array}$ & $\begin{array}{c}\square 6 \mathrm{hr} \\
15 \mathrm{~min}\end{array}$ & $20 \mathrm{~min}$ & $\begin{array}{c}30 \mathrm{~min} \text { on } \\
\text { rotation so } 1- \\
2 \mathrm{x} / \text { week }\end{array}$ & & $5.3 \%$ & 95.2 \\
\hline
\end{tabular}

\section{Appendix B}

Portland Public Elementary School Teacher Responses to Email Survey

The following eight responses were received from Portland public elementary school teachers regarding weekly outdoor time and additional opportunities for their students.

"Our kids get 20 minutes/day (or 100/week) of recess time before or after lunch. $\square$ Additionally, some teachers take another break in the morning. $\square$ I do. $\square$ So, I would say that my class gets an additional 40-60 $\square$ minutes per week of outside freedom. $\square \square I$ will tell you, though, that taking extra breaks is actually looked down upon because it is believed that it takes away from 'instructional time'. $\square$ My opinion is that it actually helps instructional time, but that's another story...

We also have a garden time at our school - each student goes outside for 30 minutes/month for that. $\square$ And I'm sure that there are many outdoor field trips that 


\section{OUTDOOR TIME IN PORTLAND ELEMENTARY SCHOOLS}

different teachers do during the year. $\square$ My grade does 2 - one to Whitaker Ponds for a half day and one to the Chinese Garden for about a half day, as well. $\square$ We also go out for Science for certain units, such as weather."

-Beverly Cleary $\square @ \square$ Fernwood Campus, $3^{\text {rd }}$ grade, SES Group: $<25 \%$

"My students have recess daily. Two times throughout the day. Lunch recess and an afternoon recess. Lunch recess is 20 min and same for afternoon recess. It is important they always get a break. We also take student on at least. 3-4 field trips each year. I also try to get them moving in the classroom when it's raining with go noodle an internet site for break times and it gets them up and moving."

-Duniway, $4^{\text {th }}$ grade, SES Group: $<25 \%$

“1. Daily/20 minutes, 2. *2-4 field trips per year, *gardening once a month/30 minutes, *extra recess each morning/15minutes."

-Beverley Cleary @ Fernwood, $2^{\text {nd }}$ grade, SES Group: $<25 \%$

"I do not take my kids out for any extra recesses. We go to Oregon Trail Overnight Camp, Talk about trees field trip, Lelooska field trip, and Newell House field trip.

$\square$ That's about it."

-Lewis, $4^{\text {th }}$ grade, SES Group: $25-50 \%$

"I can take my second grade class for one 15 min recess a day. They get one short lunch recess as well, usually about 10 mins. That would be it for outdoor opportunities." -Markham, $2^{\text {nd }}$ grade, SES Group: $51-75 \%$

"1. Students go outside each day for about 20 minutes of recess. Additionally, I take an afternoon recess for about 15 minutes every other week on average. 2. Outdoor play breaks (15 minutes every other week), Oregon Trail Overnight once a year (2 day trip a lot of outside time), walking on field trips to and from bus stops (3 trips per year), garden work (30 minutes once a year)."

-Markham, $4^{\text {th }}$ grade, SES Group: $51-75 \%$

“1) $\square$ I take my students twice a day for recess (total time about 25 minutes daily). They also get 15 minutes after lunch. 2) two outdoor field trips $x$ year. We also use the school garden as needed to do science, usually once a week from April-June. They also work in the garden per one hour once $\square$ a month."

-Bridger, $2^{\text {nd }}$ grade, SES Group: $51-75 \%$

"My students get 15 minutes a day of recess that I supervise and then about 10 minutes of lunch recess. We have a school and community garden but right now we do not go out to the garden at a scheduled time. We do have Play Works at our school and my class gets 30 minutes of game instruction each week. So far this has been outside but it will be in the classroom when we cannot go outside."

-Vestal, $3^{\text {rd }}$ grade, SES Group: $51-75 \%$ 